\title{
Carrier-free, continuous primary beer fermentation
}

\author{
Eduardo J. Pires, ${ }^{1 *}$ José A. Teixeira, ${ }^{1}$ Tomás Brányik ${ }^{2}$ and António A. Vicente ${ }^{1}$
}

\begin{abstract}
Developing a sustainable continuous fermentation reactor is one of the most ambitious tasks in brewing science, but it could bring great benefits regarding volumetric productivity to modern breweries. Immobilized cell technology is often applied to reach the large densities of yeast needed in a continuous fermentation process. However, the financial cost associated with the use of carriers for yeast immobilization is one of the major drawbacks in the technology. This work suggests that yeast flocculation could address biomass immobilization in a gas-lift reactor for the continuous primary fermentation of beer. Nearly $25 \mathrm{~g}$ dry wt $\mathrm{L}^{-1}$ of yeast was flocculated in the reactor before interruption of the fermentation. Stable sugar consumption and ethanol production ( $4.5 \%$ alcohol by volume) from an $11^{\circ} \mathrm{P}$ wort was evidenced. The key esters and higher alcohols measured in the young beer met the standards of a finished primary beer fermentation. Copyright $\odot 2014$ The Institute of Brewing \& Distilling
\end{abstract}

Keywords: continuous beer fermentation; yeast flocculation; gas-lift reactor

\section{Introduction}

Continuous beer fermentation is far from being a recent science, with patent registrations dating back the nineteenth century. Indeed, the first continuous bioreactors were designed to work with freely suspended/flocculated yeast. However, many factors hindered the evolution of 'non-immobilized' continuous systems in the late 1970s, such as: inflexibility in production rate and beer type; lack of control over wort attenuation; excess ancillary equipment needed; difficulty in maintaining production scale hygiene; yeast mutations; and wild yeast contamination (1). The idea of using solid carriers came later to overcome the pitfalls presented by 'non-immobilized' reactors, mainly (but not limited to) how to increment the productivity rate beyond the washout rate of yeast. Immobilized cell technology (ICT) uses solid carriers for cell adsorption and biofilm formation (2-9) and forced physical entrapment of yeast cells to solid matrices (10-13) as methods to increase cell density inside the reactor. The carrier cost is a key component for the financial viability of ICT $(1,14)$ and the composition of the solid matrix may also interfere in the final beer quality and flavour profile $(15,16)$. Additionally, the relatively short lifespan of a single yeast cell (17) results in an accumulation of dead biomass in the biocatalyst, thus demanding constant replacement (18).

Continuous beer fermentation depends on a high density of yeast cells immobilized inside a bioreactor. The considerable amount of yeast allows a short residence time for the wort in the bioreactor. The wort is continuously supplied for beer production. This feature results in high productivity and reduced space and time being needed to reach the final product $(15,19,20)$. Despite being very attractive, the continuous fermentation of beer is still marginalized to laboratory benches, pilot plants and a few courageous companies such as Dominion Breweries of New Zealand, which have been using continuous brewing since 1959 with a setup based on flocculated biomass (15).

Some brewing yeast strains are remarkably flocculent and this feature is widely used to harvest yeast at the end of primary fermentation (21,22). Flocculation is a multifactorial inheritance triggered by both genetic and environmental factors (22). The most accepted mechanism supporting yeast flocculation is through the expression of FLO genes encoding specialized cell wall proteins (flocculins), which are able to bind to sugar residues in the cell walls of adjacent cells $(22,23)$. Hydrodynamic conditions in the reactor have a direct impact on flocculation and floc size, as the liquid agitation increases the chances of cell collisions, but strong movement breaks up cell clusters (24). Moreover, the higher the concentration of yeast cells that are in suspension, the greater the number of collisions, and consequently the faster the formation of flocs (25). Additionally, factors that increase cell-surface hydrophobicity and/or that decrease the repulsive negative electrostatic charges on the cell wall cause stronger flocculation, as they increase the probability of cell-to-cell contact (26). This self-aggregation characteristic is a free-of-charge way of immobilization and seems to have been poorly exploited in recent ICT setups.

Gas-lift bioreactors are remarkably efficient in regard to mass transfer for either liquid-liquid or solid-liquid phases triggered by rapid mixing, low shear stress, simple design and low energy consumption $(27,28)$. The low shear environment provides excellent conditions for ICT implementation (29) and has previously been adopted for continuous beer fermentation $(3,13)$. This work examines the feasibility of self-aggregation as a single biomass immobilization method for young beer production in a gas-lift reactor.

\footnotetext{
* Correspondence to: E. J. Pires, Institute for Biotechnology and Bioengineering, Centre for Biological Engineering, Universidade do Minho, Campus de Gualtar, 4710-057, Braga, Portugal. E-mail: eduardo.pires@deb.uminho.pt

1 Institute for Biotechnology and Bioengineering, Centre for Biological Engineering, Universidade do Minho, Campus de Gualtar, 4710-057, Braga, Portugal

2 Department of Biotechnology, Institute of Chemical Technology Prague, Technická 5, 16628 Prague 6, Czech Republic
} 


\section{Material and methods}

\section{Brewing yeast}

The flocculent Saccharomyces pastorianus strain no. 96 from the Culture Collection of Brewing Yeast (Research Institute of Brewing and Malting plc, Prague, Czech Republic) was used. It was inoculated onto a complex media of the following composition $\left(\mathrm{g} \mathrm{L}^{-1}\right)$ : glucose, 30; $\mathrm{KH}_{2} \mathrm{PO}_{4}, 5 ; \mathrm{MgSO}_{4} 7 \mathrm{H}_{2} \mathrm{O}, 0.4 ;\left(\mathrm{NH}_{4}\right)_{2} \mathrm{SO}_{4}$, 2; yeast extract, 2; agar, 20. The medium was prepared in Petri dishes for the isolation of yeast colonies. A colony was then inoculated in $400 \mathrm{~mL}$ of $5^{\circ}$ Plato wort and incubated at $20^{\circ} \mathrm{C}, 120 \mathrm{rpm}$, for $48 \mathrm{~h}$ before use as an inoculum for the gas-lift reactor.

\section{Beer wort}

Pale wort concentrate was acquired from the Research Institute of Brewing and Malting (Prague). It was diluted to the final desired concentration -5 and $11^{\circ} \mathrm{P}$. The final wort was filled into $20 \mathrm{~L}$ polyethylene carboys (Nalgene, USA) and autoclaved for $3.5 \mathrm{~h}$.

\section{Continuous fermentation}

The experiment was carried out using a Perspex gas-lift reactor with $4 \mathrm{~L}$ of total work volume. Gas flow was kept constant at $0.5 \mathrm{~L}$ $\min ^{-1}$ by the GFC17 mass controller (Aalborg, USA). The temperature was held at $15^{\circ} \mathrm{C}$ using a Julabo $\mathrm{F} 32$ refrigeration/heating circulator (Julabo, Germany). The dilution rate was kept at $0.043 \mathrm{~h}^{-1}$ using a peristaltic pump PDC 83 (Kouřil, Czech Republic). Figure 1 shows the scheme of the entire equipment setup used in the current work.

The reactor was sterilized by bleaching, using a $3 \%(\mathrm{v} / \mathrm{v})$ solution of commercial sodium hypochlorite with $1.5 \%$ of active chlorine, $48 \mathrm{~h}$ prior to use. After this time, the solution was discarded and $50 \mathrm{~L}$ of sterile water was used to wash the reactor. It was then filled with $5^{\circ} \mathrm{P}$ wort and inoculated.

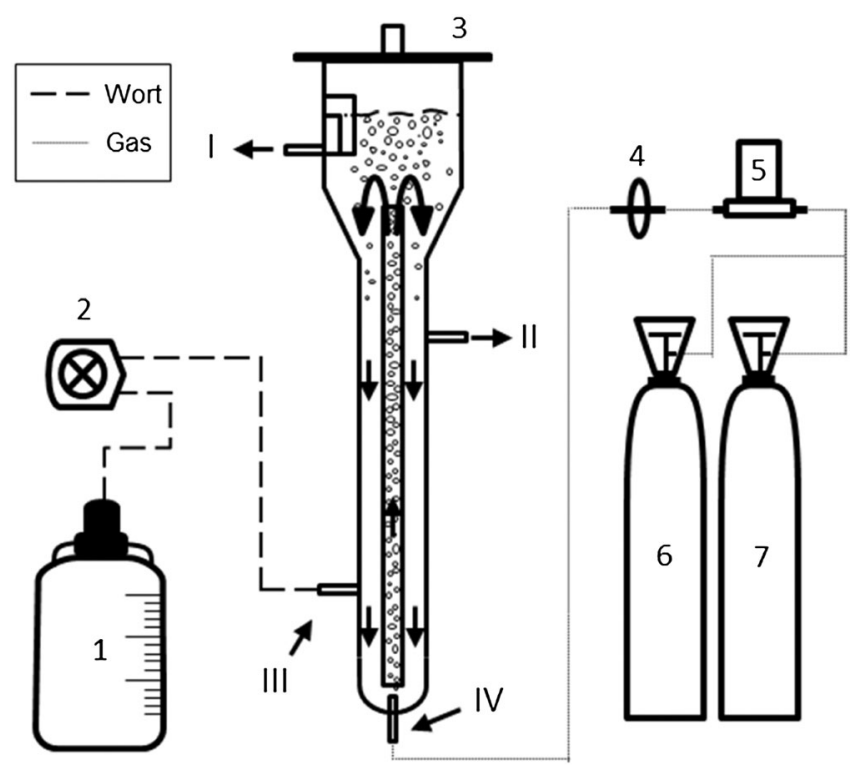

Figure 1. Immobilized yeast bioreactor system used in the current work: 1 , wort barrel; 2, peristaltic pump; 3, gas-lift reactor; 4 , air filter; 5 , flow mass controller; 6 , pressurized air; $7, \mathrm{CO}_{2}$ bottle; I, green beer outflow/sampling point; II, biomass sampling point; III, wort inlet; IV, gas sparger.
Batch growth was performed in the first $48 \mathrm{~h}$, using pressurized air as the gas supply at $500 \mathrm{~mL} \mathrm{~min}^{-1}$. After that, the gas was changed to $\mathrm{CO}_{2}$ at the same flow rate and the continuous phase was started with a $5^{\circ} \mathrm{P}$ wort supply at a $0.043 \mathrm{~h}^{-1}$ dilution rate. Four days later, the wort supply was changed to $11^{\circ} \mathrm{P}$ wort keeping the dilution rate unchanged.

\section{Biomass measurements}

The flocculated biomass was evaluated daily. Three $15 \mathrm{~mL}$ plastic falcon tubes were dried at $105^{\circ} \mathrm{C}$ for $12 \mathrm{~h}$ and weighed. Then $10 \mathrm{~mL}$ of cell suspension from the reactor was added to each one of them and centrifuged at $4000 \mathrm{~g}$ for $5 \mathrm{~min}$. The liquid phase was discarded and the tubes were dried $\left(105^{\circ} \mathrm{C}\right)$ for $24 \mathrm{~h}$ prior to weighing. Control blank experiments were carried out using the inlet wort to correct for the presence of trub-like components that could interfere with weighing.

\section{Sugars and ethanol measurements}

A daily sample was taken from the reactor's outflow for green beer analysis. Sugars and ethanol were evaluated using highperformance liquid chromatography (HPLC) with an Agilent 1100 series equipped with Agilent G 1362A RID detector (Agilent, USA). The column used was the Rezex ${ }^{\mathrm{Tm}} \mathrm{RSO}-$ Oligosaccharide $200 \times 10 \mathrm{~mm}$ (Phenomenex, USA) and the eluent was deionized degassed water pumped at a flow of $0.4 \mathrm{~mL} / \mathrm{min}$. Sugar and ethanol standards were calibrated previous to wort and young beer measurements using the following reagents: D-fructose (Chemapol, Praha, Czech Republic), D-maltose monohydrate (Fluka, Japan), D-glucose (Fluka, Japan), maltotriose (Sigma, USA) and ethanol (Sigma, USA).

\section{Measurement of flavour-active compounds}

Higher alcohols and esters were analysed by gas chromatography using an Agilent HP-6890N gas chromatography-mass spectrometry system (Agilent Technologies, USA) coupled to a mass detector Agilent 5975B Inert MSD (Agilent Technologies, USA). Compounds were separated on an InnoWax $(30 \mathrm{~m} \times 0.25$ $\mathrm{mm} \times 0.25 \mu \mathrm{m}$ ) column (Agilent Technologies, USA). Helium was used as the carrier gas at a flow rate of $6 \mathrm{~mL} / \mathrm{min}$. The oven temperature was programmed to a start temperature of $30^{\circ} \mathrm{C}$ for $10 \mathrm{~min}$, then it was raised at $2^{\circ} \mathrm{C} \mathrm{min}^{-1}$ to $52^{\circ} \mathrm{C}(2 \mathrm{~min})$, plus $2^{\circ} \mathrm{C}$ $\min ^{-1}$ up to $65^{\circ} \mathrm{C}$ and finally up to $250^{\circ} \mathrm{C}$ at $5^{\circ} \mathrm{C} \min ^{-1}(3 \mathrm{~min})$. Samples were injected at $260^{\circ} \mathrm{C}$. Standards were analysed previous to samples using 2-methyl-1-butanol (>98\%), 3-methyl1-butanol (>98.5\%), isobutanol (>99\%), isoamyl acetate ( 99\%), ethyl acetate $(99.7 \%)$, ethyl butyrate $(>98 \%)$, ethyl hexanoate (>99\%), ethyl octanoate (>98\%), ethyl decanoate (>99\%) and 2-phenyl ethyl acetate (>99\%) (Fluka, Germany). Internal standards used were 3-octanol (99\%; Aldrich, USA) and ethyl heptanoate (99\%; Aldrich, Germany).

\section{Results and discussion}

\section{Biomass build-up}

One of the main conditions in the environment that triggers yeast flocculation is the reduced amount of sugars present at the end of primary fermentation $(22,30,31)$. For this reason diluted $\left(5^{\circ} \mathrm{P}\right)$ wort was used in the start-up of the gas-lift reactor. Unexpectedly, this lower input of sugars did not favour biomass 
accumulation, which was only observed after changing wort barrels for inletting the $11^{\circ} \mathrm{P}$ wort (Fig. 2). Considering that the dilution rate and other parameters were kept constant during both the 5 and $11^{\circ} \mathrm{P}$ worts, nutrients may have been restrictive for biomass growth in the course of the former stage, otherwise biomass build-up in this phase should have been more expressive. Moreover, as there were still sugars present in the outflow current (Table 1), there might have been a lack of assimilable nitrogen throughout the inlet of the $5^{\circ} \mathrm{P}$ wort. Concentrated wort syrups, as used in this work, may have insufficient levels of assimilable nitrogen (32). In fact, although flocculation could be visualized through the Perspex reactor, nitrogen starvation may have reduced cell division and biomass growth (33). Recently, Ogata (23) suggested that the flocculins in $S$. pastorianus are expressed in response to nutritional starvation on account of the expression of Lg-Flo1 (flocculin-encoding gene), which is regulated by a nitrogen catabolite repression-like mechanism. These pieces of evidence could explain why biomass was not growing during the $5^{\circ} \mathrm{P}$ wort injection, but the biomass still flocculated.

Many factors could explain the strong biomass accumulation observed throughout the $11^{\circ} \mathrm{P}$ wort inlet. First, more nutrients were flowing in the current inlet if compared with the previous $5^{\circ} \mathrm{P}$ wort, supporting yeast growth. In the advanced stages of $11^{\circ} \mathrm{P}$ wort supply, the environment inside the gas-lift was poor in sugars and rich in ethanol (around $4.5 \% \mathrm{v} / \mathrm{v}$ ). Ethanol has a positive effect on flocculation, as it reduces the negative electrostatic repulsion between cells (34) and increases cell-surface hydrophobicity (35). Moreover, it has also been suggested that ethanol acts directly on the expression of FLO genes $(36,37)$. Together with constant agitation in both the 5 and $11^{\circ} \mathrm{P}$ phases, the growing number of cells probably favoured cell encounter and collisions, enhancing flocculation in the current setup.

As no solid carriers were used in this study, immobilization of yeast cells inside the gas-lift reactor depended exclusively on flocculation. At the end of the reactor's operation, the biomass suspended inside the gas-lift reactor was nearly $25 \mathrm{~g} \mathrm{~L}^{-1}$ in dry matter and most of this biomass was flocculated (data not shown). The separation of free cells from flocks is virtually impossible owing to the small size of the flocks and the dynamics of cell aggregation $(38,39)$. Hence, the biomass expressed in Fig. 2 denotes the total biomass ( $X_{\text {tot }}=$ flocs + free cells) suspended in the system.

Comparing $X_{\text {tot }}$ in different setups used by other authors is a difficult task. Whereas cell adsorption is very dynamic, entrapment-based studies often do not discuss biomass growth on biocatalysts. For example, Tata and co-workers (8) compared a number of two-stage systems for continuous beer production. Each of these systems was composed of two reactors connected in series: two fluidized bed reactors with porous glass beads for cell immobilization and two loop reactors with a silicon carbide cartridge for yeast load. The maximum values of $X_{\text {tot }}$ reported by the authors for each of these systems were 29.7 and $18.2 \mathrm{~g}$ cell dry wt $\mathrm{L}^{-1}$, respectively. In further work involving continuous primary beer fermentation carried out by Brányik et al. (40), the $X_{\text {tot }}$ reported using a gas-lift reactor with a lignocellulosic carrier obtained from brewer's spent grains varied from 9.3 to $10.5 \mathrm{~g}$ cell dry wt $\mathrm{L}^{-1}$. However, the yeast load of a specific system does not necessarily reflect good results. Therefore, the performance of different ICT setups must be compared in terms of specific saccharide consumption $\left(r_{\mathrm{s}}\right)$ and volumetric ethanol productivity $\left(r_{\mathrm{p}}\right)(8,41)$ as further discussed.

\section{Sugars consumption and ethanol yield}

The efficacy of the gas-lift reactor for primary beer fermentation has long been studied, using several types of yeast immobilization method $(13,40,42)$. The present work focused on self-aggregation to attain the biomass needed for the continuous primary fermentation of the wort provided. As temperature and dilution rate were kept constant during the entire experiment, sugar consumption and ethanol production were directly dependent on the $X_{\text {tot }}$ and wort gravity. Table 1 shows in detail the amount of each fermentable sugar present at the inlet wort for both the 5 and the $11^{\circ} \mathrm{P}$ stages. It also shows the residual content of these sugars and the ethanol present in the green beer through the course of the continuous fermentation. Changing the composition of wort during the continuous phase caused an adaption phase between the $144 \mathrm{~h}$ (start of inlet supply of $11^{\circ} \mathrm{P}$ barrel) and $388 \mathrm{~h}$ (beginning of steady phase) period of the continuous fermentation (Fig. 2). Environmental changes are known to alter yeast metabolism,

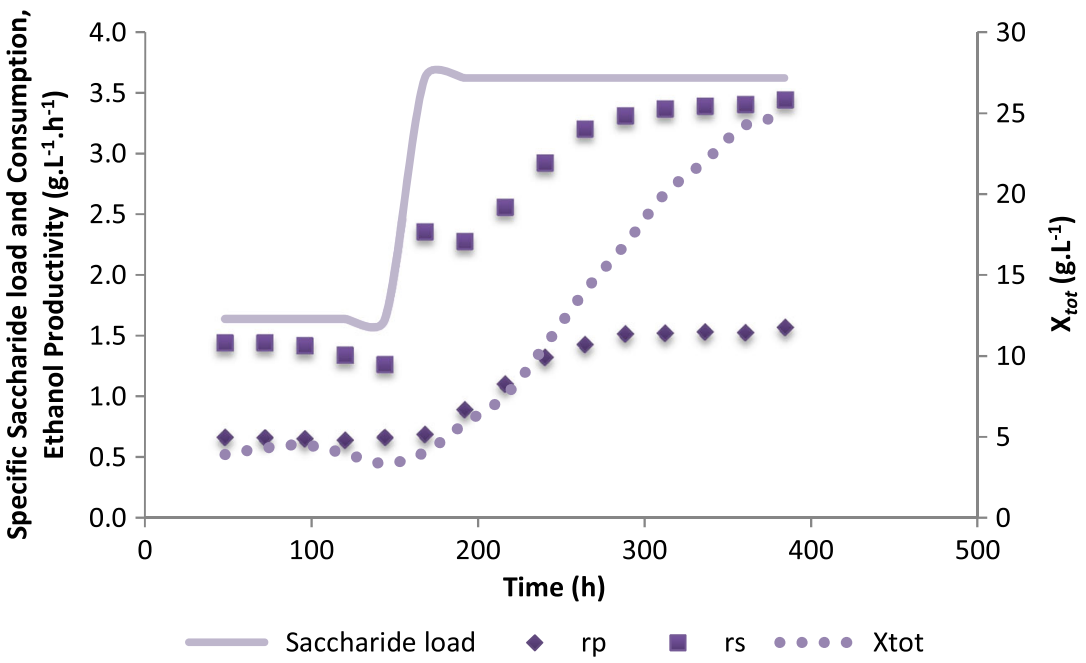

Figure 2. Specific saccharide load and consumption $\left(r_{\mathrm{s}}\right)$, ethanol productivity $\left(r_{\mathrm{p}}\right)$ and total immobilized biomass $\left(X_{\text {tot }}\right)$ inside the reactor through the primary continuous fermentation. This figure is available in colour online at wileyonlinelibrary.com/journal/brewing. 


\begin{tabular}{|c|c|c|c|c|c|c|c|c|}
\hline Sample type & Time (h) & $\begin{array}{c}\text { Maltotriose } \\
\left(\mathrm{gL}^{-1}\right)\end{array}$ & $\begin{array}{c}\text { Maltose } \\
\left(\mathrm{gL}^{-1}\right)\end{array}$ & $\begin{array}{l}\text { Glucose } \\
\left(g^{-1}\right) e\end{array}$ & $\begin{array}{c}\text { Fructose } \\
\left(\mathrm{gL}^{-1}\right)\end{array}$ & $\begin{array}{l}\text { ABV } \\
(\%)\end{array}$ & $\begin{array}{c}\text { Ethanol } \\
\left(\mathrm{g} \mathrm{L}^{-1}\right)\end{array}$ & $\begin{array}{c}X_{\text {tot }} \\
\left(\mathrm{g} \text { dry } w \mathrm{~L}^{-1}\right)\end{array}$ \\
\hline $5^{\circ} \mathrm{P}$ wort & - & 6.45 & 23.49 & 5.71 & 2.46 & - & - & - \\
\hline GB5 & 48 & 2.34 & 1.76 & 0.14 & 0.32 & 1.96 & 15.50 & 3.9 \\
\hline GB5 & 72 & 2.29 & 1.69 & 0.17 & 0.33 & 1.96 & 15.48 & 4.3 \\
\hline GB5 & 96 & 2.61 & 1.93 & 0.22 & 0.36 & 1.93 & 15.26 & 4.5 \\
\hline GB5 & 120 & 3.24 & 2.85 & 0.30 & 0.48 & 1.90 & 14.99 & 4.0 \\
\hline GB5 & 144 & 3.63 & 4.11 & 0.34 & 0.55 & 1.97 & 15.57 & 3.4 \\
\hline $11^{\circ} \mathrm{P}$ wort & - & 13.69 & 50.96 & 12.91 & 6.69 & - & - & - \\
\hline GB11 & 168 & 7.59 & 18.61 & 1.57 & 1.70 & 2.04 & 16.09 & 4.1 \\
\hline GB11 & 192 & 8.36 & 20.18 & 1.22 & 1.48 & 2.63 & 20.81 & 5.8 \\
\hline GB11 & 216 & 7.68 & 14.38 & 1.17 & 1.45 & 3.26 & 25.72 & 7.5 \\
\hline GB11 & 240 & 6.24 & 8.31 & 0.68 & 1.02 & 3.90 & 30.78 & 10.6 \\
\hline GB11 & 264 & 4.78 & 3.90 & 0.39 & 0.71 & 4.21 & 33.29 & 14.0 \\
\hline GB11 & 288 & 3.78 & 2.71 & 0 & 0.53 & 4.47 & 35.28 & 16.8 \\
\hline GB11 & 312 & 3.20 & 2.20 & 0 & 0 & 4.48 & 35.41 & 20.0 \\
\hline GB11 & 336 & 3.03 & 1.97 & 0 & 0 & 4.52 & 35.68 & 22.0 \\
\hline GB11 & 360 & 2.75 & 1.92 & 0 & 0 & 4.50 & 35.58 & 24.2 \\
\hline GB11 & 384 & 2.56 & 1.31 & 0 & 0 & 4.62 & 36.54 & 24.8 \\
\hline
\end{tabular}

which can then take some time to adapt to the new conditions (43). Thus, instead of changing the wort gravity, the dilution rate should have been raised gradually, using a steady wort gravity, to avoid delays. After the adaption stage, the consumption of sugars was satisfactory and stable until the end of the fermentation trial. At this time, from the original $84.25 \mathrm{~g} \mathrm{~L}^{-1}$ of fermentable sugars present in the inlet $\left(11^{\circ} \mathrm{P}\right)$ wort, only about $5 \mathrm{~g} \mathrm{~L}^{-1}$ was present in the outflow. These residual sugars corresponded to maltose and maltotriose (on average 2 and $3 \mathrm{gL}^{-1}$, respectively). Not surprisingly, glucose and fructose were not present in the young beer at this phase (Table 1) owing to preferential sugar consumption of monosaccharides by yeast (43-46). Furthermore, a reduced amount of fermentable sugars is required in the green beer for further carbon dioxide development in the maturation stage.

The $r_{\mathrm{s}}$ value designates the consumption rate of all the fermentable sugars $\left(\mathrm{gL}^{-1} \mathrm{~h}^{-1}\right)$ in the course of the retention time. Through the initial $5^{\circ} \mathrm{P}$ stage, the average $r_{\mathrm{s}}$ measured was $0.66 \mathrm{~g} \mathrm{~L}^{-1} \mathrm{~h}^{-1}$ and this value increased during the steady phase of $11^{\circ} \mathrm{P}$ to $3.4 \mathrm{~g} \mathrm{~L}^{-1} \mathrm{~h}^{-1}$ (Fig. 2). This consumption rate is consistent with $r_{\mathrm{s}}$ values reported by other studies regarding continuous primary beer fermentation $(3,8,13,40,42,47)$.

Ethanol yield obtained during the steady $11^{\circ} \mathrm{P}$ phase was very satisfactory and an average of $4.5 \%(\mathrm{v} / \mathrm{v})$ alcohol by volume was measured during this period (Table 1). As the total retention time $\left(\mathrm{RT}_{\text {tot }}\right)$ was $23.25 \mathrm{~h}$, the average $r_{\mathrm{p}}$ measured in the course of steady phase of $11^{\circ} \mathrm{P}$ wort was $1.54 \mathrm{~g} \mathrm{~L}^{-1} \mathrm{~h}^{-1}$ (Fig. 2). In the studies involving entrapped yeast carried out by Smogrovicová and coworkers (42), they reported $r_{\mathrm{p}}$ values from 1.7 to $2.4 \mathrm{~g} \mathrm{~L}^{-1} \mathrm{~h}^{-1}$. However, the higher yields of ethanol reported by these authors were followed by higher amounts of residual sugars in the young beer. Short $\mathrm{RT}_{\text {tot }}$ may ultimately increase $r_{\mathrm{s}}$ and $r_{\mathrm{p}}$, but without enough biomass, the result will be an unfinished primary fermentation. The $r_{\mathrm{p}}$ values observed in the current study are also in accordance with previous reports involving continuous primary beer fermentation: $1.6 \mathrm{~g} \mathrm{~L}^{-1} \mathrm{~h}^{-1}$ (40) and $2 \mathrm{~g} \mathrm{~L}^{-1} \mathrm{~h}^{-1}$ (47).

\section{Volatile compounds profile}

The consequences of continuously operated systems using ICT over the aroma profile produced during primary continuous beer fermentation have previously been reviewed by Willaert and Nedovic (15).

The great majority (nearly $80 \%$ ) of higher alcohols present in the final beer are produced by the yeast during primary fermentation $(43)$ either from catabolism $(48,49)$ or from the synthesis of amino acids (50). Higher alcohols not only contribute directly to the final beer aroma, but can also be used as precursors in the synthesis of esters. Data involving the production of higher alcohols using ICT are rather inconsistent as some works have reported a low production of higher alcohols using ICT (51-53), while others have observed even higher values of fusel alcohols in continuous mode when compared with batch fermentation (54). In the current work, isoamyl alcohol (3-methyl-1-butanol) and the active amyl alcohol (2-methyl-1-butanol) were measured together and are henceforth reported as amyl alcohols. The threshold for these alcohols when considered together is $50 \mathrm{mg} \mathrm{L}^{-1}$ (55). Higher alcohols measured in the green beer produced in the current work are presented in Table 2. When fermentation reached a steady state upon $11^{\circ} \mathrm{P}$ wort supply, the threshold of amyl alcohols was achieved. At this time, the $X_{\text {tot }}$ was nearly $14 \mathrm{~g}$ dry wt $\mathrm{L}^{-1}$ and the amyl alcohol concentration was $52 \mathrm{mg} \mathrm{L}^{-1}$. Levels of these alcohols changed slightly $\left(55 \mathrm{mg} \mathrm{L}^{-1}\right)$ up until the interruption of fermentation when $X_{\text {tot }}$ was close to $25 \mathrm{~g}$ dry wt $\mathrm{L}^{-1}$. Using polyvinyl alcohol for yeast entrapment, Smogrovicová and co-workers (56) observed $57.8 \mathrm{mg} \mathrm{L}^{-1}$ of amyl alcohol in their young beer. The amyl alcohol yield measured in the Brányik et al. (47) setup using brewer's spent grains as yeast carriers was somewhat higher and $60.1 \mathrm{mg} \mathrm{L}^{-1}$ was measured. In an early study, Smogrovicová and Dömény used calcium-pectate beads for yeast immobilization and observed a similar amyl alcohol content of $56.8 \mathrm{mg} \mathrm{L}^{-1}$ (52). In this particular last mentioned work, the authors used the same yeast strain and temperature $\left(15^{\circ} \mathrm{C}\right)$ and a similar wort gravity $\left(11.5^{\circ} \mathrm{P}\right)$ as used in the current work, which may also explain the similarity in the amyl alcohol content. Higher 
Table 2. Flavour-active compounds present in the outflow (young beer)

\begin{tabular}{|c|c|c|c|c|}
\hline \multirow[t]{2}{*}{ Compound } & \multicolumn{4}{|c|}{ Concentration $\left(\mathrm{mg} \mathrm{L}^{-1}\right)$ at: } \\
\hline & $120 \mathrm{~h}$ & $216 \mathrm{~h}$ & $264 \mathrm{~h}$ & $384 \mathrm{~h}$ \\
\hline Ethyl acetate & 3.33 & 15.38 & 28.86 & 36.71 \\
\hline Isoamyl acetate & 0.09 & 0.65 & 1.24 & 1.99 \\
\hline Ethyl butyrate & - & 0.02 & 0.03 & 0.07 \\
\hline Phenyl ethyl acetate & 0.30 & 0.33 & 0.49 & 0.52 \\
\hline Ethyl hexanoate (caproate) & 0.008 & 0.04 & 0.05 & 0.14 \\
\hline Ethyl octanoate (caprylate) & 0.005 & 0.02 & 0.07 & 0.14 \\
\hline Ethyl decanoate (caprate) & 0.001 & 0.004 & 0.04 & 0.04 \\
\hline Total esters & 3.73 & 16.44 & 30.78 & 39.60 \\
\hline Amyl alcohols ${ }^{a}$ & 24.55 & 28.24 & 52.37 & 55.50 \\
\hline Isobutanol & - & 4.76 & 11.05 & 11.55 \\
\hline 2-Phenylethanol & 40.28 & 40.42 & 61.49 & 67.55 \\
\hline Total higher alcohols & 64.83 & 73.43 & 124.91 & 134.60 \\
\hline $\mathrm{A} / \mathrm{E}^{\mathrm{b}}$ & 17.38 & 4.47 & 4.06 & 3.40 \\
\hline
\end{tabular}

alcohols production is totally dependent on the fermentation conditions adopted and is usually enhanced by conditions that favour yeast growth $(43,57)$. The isobutanol levels measured in the current work are also in agreement with published data for green beer produced by ICT $(47,52)$. Surprisingly, the level of 2-phenylethanol was high in the green beer produced from $11^{\circ} \mathrm{P}$ wort (Table 2), which could ultimately contribute to a pleasant floral aroma in the finished beer.

Esters are pleasant aroma compounds present in beer and contributing positive notes such as flowers, honey and fruity. They are mainly produced during the initial phase of primary fermentation, by the action of yeast acyltransferase activities catalysing the condensation reactions between either acetyl/acyl-CoA and higher alcohols or ethanol. Accordingly, successful primary beer fermentation must produce enough esters that will be present in the final product. The ester most present in beer is the fruit/solvent-like ethyl acetate, which has a flavour threshold around $25-30 \mathrm{mg} \mathrm{L}^{-1}(55,58)$. For the current work, this threshold was reached at the beginning of the steady phase of the continuous experiment $\left(11^{\circ} \mathrm{P}\right)$. From this time onwards, the ethyl acetate values changed only slightly up to $36.7 \mathrm{mg} \mathrm{L}^{-1}$ at the end of the continuous fermentation. This number is higher than any other data found in the literature and is also in accordance with past works regarding the overproduction of ethyl acetate by ICT systems (3,52,56,59-61). Ester production is greatly influenced by yeast strain, pitching rate, temperature, top pressure, aeration and agitation (43). An increased production of acetate esters by immobilized yeast was evidenced during beer fermentation owing to higher ATF1 gene expression in immobilized cell population when compared with free cells (62). Alcohol acetyltransferase (ATF1 and ATF2) gene expressions are the most important aspects determining acetate ester levels during fermentation (63). Isoamyl acetate is also an important constituent of the final beer with threshold values around $1.2 \mathrm{mg} \mathrm{L}^{-1}$ (55). The performance of the current setup regarding the production of isoamyl acetate was also superior to other data involving primary beer fermentation $(3,51,59)$. However, very high isoamyl acetate levels are not desired in lager beers.

Medium-chain fatty acid (MCFA) ethyl esters such as ethyl hexanoate (caproate), ethyl octanoate (caprylate) and ethyl

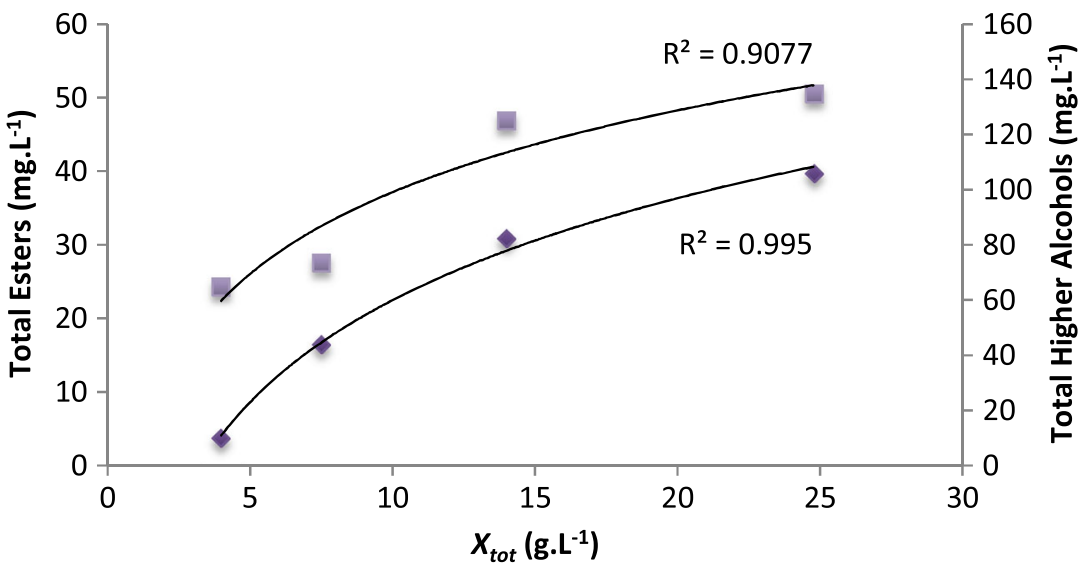

- Esters vs Xtot Higher Alcohols vs Xtot

Figure 3. Correlations between the total biomass $\left(X_{\text {tot }}\right)$ present in the gas-lift reactor and the outlet content of total esters and higher alcohols. This figure is available in colour online at wileyonlinelibrary.com/journal/brewing. 
decanoate (caprate) are produced at much lower levels than acetate esters in beer (58). Thus, ICT studies often focus more attention on the acetate family rather than the ethyl ester group. The MCFA ethyl esters measured in this study were consistent with past records involving immobilized yeast during primary beer fermentation (52,56,59-61). Table 2 shows the ester profile of the green beer at different fermentation times for the present work.

Both higher alcohols and esters present in the green beer from the outflow of the gas-lift reactor could be correlated with $X_{\text {tot }}$ (Fig. 3) for a specific sampling time. This data can give crucial insights for planning new continuous fermentations. The use of higher pitching yeast rates on the start-up of the reactor may also accelerate the expected results.

\section{Conclusions}

The current work has shown that it is feasible to use flocculation as a single method of yeast immobilization in a gas-lift bioreactor for continuous primary beer fermentation. This fact is supported not only by the successful tendency for biomass accumulation relying only on self-aggregation of yeast cells, but also by the good performance on specific saccharide consumption and ethanol volumetric productivity demonstrated in this work. The feasibility of biomass accumulation through flocculation is supported by hydrodynamic (favouring cell-cell collisions) and environmental conditions (low sugar and high ethanol) in the gas-lift reactor. The data obtained was comparable to other ICT systems using several types of yeast carriers in gas-lift reactors. It is important to bear in mind that, although these results are very promising, the experiments were carried out at the laboratory scale and more experiments should be carried out if this setup is to be scaled up. Keeping the composition of the wort as constant as possible is highly recommended as otherwise it could interfere with biomass build-up during the start-up of the reactor. A carrier-free setup would provide advantages concerning the financial cost and management of the reactor when scaled up.

\section{Acknowledgements}

Eduardo Pires gratefully acknowledges the Fundação para a Ciência e a Tecnologia (FCT, Portugal) for the PhD fellowship support (SFRH/BD/61777/2009) and Marcel Karabín from the Department of Biotechnology of the Institute of Chemical Technology (Prague) for technical support. The financial contributions of the EU FP7 project EcoBioCAP - Ecoefficient Biodegradable Composite Advanced Packaging, grant agreement no. 265669 as well as of the Grant Agency of the Czech Republic (project GAČR P503/12/1424) are also gratefully acknowledged.

\section{References}

1. Virkajärvi, I. (2001) Feasibility of continuous main fermentation of beer using immobilized yeast, Doctoral Dissertation, Technical Research Centre of Finland - VTT, Helsinki University of Technology (Espoo, Finland).

2. Berlowska, J., Kregiel, D., and Ambroziak, W. (2013) Enhancing adhesion of yeast brewery strains to chamotte carriers through aminosilane surface modification, World J. Microbiol. Biotechnol. 29, 1307-1316.

3. Branyik, T., Silva, D. P., Vicente, A. A., Lehnert, R., E Silva, J. B., Dostalek, P., and Teixeira, J. A. (2006) Continuous immobilized yeast reactor system for complete beer fermentation using spent grains and corncobs as carrier materials, J. Ind. Microbiol. Biotechnol. 33, 1010-1018.

4. Brányik, T., Vicente, A. A., Oliveira, R., and Teixeira, J. A. (2004) Physicochemical surface properties of brewing yeast influencing their immobilization onto spent grains in a continuous reactor, Biotechnol. Bioeng. 88, 84-93.

5. Brányik, T., Vicente, A. A., Cruz, J. M., and Teixeira, J. A. (2001) Spent grains - a new support for brewing yeast immobilisation, Biotechnol. Lett. 23, 1073-1078.

6. Nedovic, V. A., Cukalovic, I. L., Bezbradica, D., Obradovic, B., and Bugarski, B. (2005) New porous matrices and procedures for yeast cell immobilisation for primary beer fermentation, in Proc. Eur. Brew. Conv. Congr. Prague, pp. 401-413, Fachverlag Hans Carl, Nürenberg.

7. Verbelen, P. J., De Schutter, D. P., Delvaux, F., Verstrepen, K. J., and Delvaux, F. R. (2006) Immobilized yeast cell systems for continuous fermentation applications, Biotechnol. Lett. 28, 1515-1525.

8. Tata, M., Bower, P., Bromberg, S., Duncombe, D., Fehring, J., Lau, V. V., Ryder, D., and Stassi, P. (1999) Immobilized yeast bioreactor systems for continuous beer fermentation, Biotechnol. Prog. 15, 105-113.

9. Bezbradica, D., Obradovic, B., Leskosek-Cukalovic, I., Bugarski, B., and Nedovic, V. (2007) Immobilization of yeast cells in PVA particles for beer fermentation, Process Biochem. 42, 1348-1351.

10. Pilkington, H., Margaritis, A., Mensour, N., Sobczak, J., Hancock, I., and Russell, I. (1999) Kappa-carrageenan gel immobilisation of lager brewing yeast, J. Inst. Brew. 105, 398-404.

11. Almonacid, S. F., Nájera, A. L., Young, M. E., Simpson, R. J., and Acevedo, C. A. (2012) A comparative study of stout beer batch fermentation using free and microencapsulated yeasts, Food Bioprocess Technol. 5, 750-758.

12. Smogrovicova, D., Domény, Z., Gemeiner, P., Malovikova, A., and Sturdik, E. (1997) Reactors for continuous primary beer fermentation using immobilised yeast, Biotechnol. Techn. 11, 261-264.

13. Dömény, Z., Smogrovicová, D., Gemeiner, P., Sturdík, E., Pátková, J., and Malovíková, A. (1998) Continuous secondary fermentation using immobilised yeast, Biotechnol. Lett. 20, 1041-1045.

14. Virkajärvi, I. (1999) Profiting from immobilized fermentation, in Fifth Aviemore Conference on Malting, Brewing and Distilling, pp. 290-293, Institute of Brewing, London.

15. Willaert, R., and Nedovic, V. A. (2006) Primary beer fermentation by immobilised yeast - a review on flavour formation and control strategies, J. Chem. Technol. Biotechnol. 81, 1353-1367.

16. Virkajarvi, I., and Pohjala, N. (2000) Primary fermentation with immobilized yeast: Some effects of carrier materials on the flavour of the beer, J. Inst. Brew. 106, 311-318.

17. Mortimer, R. K. and Johnston, J. R. (1959) Life span of individual yeast cells, Nature 183, 1751-1752.

18. Kuřec, M., Baszczyňski, M., Lehnert, R., Mota, A., Teixeira, J. A., and Brányik, T. (2009) Flow cytometry for age assessment of a yeast population and its application in beer fermentations, J. Inst. Brew. 115, 253-258.

19. Linko, M., Haikara, A., Ritala, A., and Penttila, M. (1998) Recent advances in the malting and brewing industry, J. Biotechnol. 65, 85-98.

20. Pilkington, P. H., Margaritis, A., Mensour, N. A., and Russell, I. (1998) Fundamentals of immobilized yeast cells for continuous beer fermentation: A review, J. Inst. Brew. 104, 19-31.

21. Powell, C. D., Quain, D. E., and Smart, K. A. (2003) The impact of brewing yeast cell age on fermentation performance, attenuation and flocculation, FEMS Yeast Res. 3, 149-157.

22. Soares, E. V. (2011) Flocculation in Saccharomyces cerevisiae: A review, J. Appl. Microbiol. 110, 1-18.

23. Ogata, T. (2012) Nitrogen starvation induces expression of Lg-FLO1 and flocculation in bottom-fermenting yeast, Yeast 29, 487-494.

24. Klein, J., Maia, J., Vicente, A. A., Domingues, L., Teixeira, J. A., and Jurascik, M. (2005) Relationships between hydrodynamics and rheology of flocculating yeast suspensions in a high-cell-density airlift bioreactor, Biotechnol. Bioeng. 89, 393-399.

25. van Hamersveld, E. H., van der Lans, R. G. J. M., and Luyben, K. C. A. M. (1997) Quantification of brewer's yeast flocculation in a stirred tank: Effect of physical parameters on flocculation, Biotechnol. Bioeng. 56, 190-200.

26. Jin, Y.-L. and Speers, R. A. (2000) Effect of environmental conditions on the flocculation of Saccharomyces cerevisiae, J. Am. Soc. Brew. Chem. 58, 108-116.

27. Merchuk, J. C. (1991) Shear effects on suspended cells, Adv. Biochem. Eng./Biotechnol. 44, 65-95.

28. Chisti, Y. and Moo-Young, M. (1989) On the calculation of shear rate and apparent viscosity in airlift and bubble column bioreactors, Biotechnol. Bioeng. 34, 1391-1392. 
29. Chang, C.-M., Lu, W. J., Own, K. S., and Hwang, S.-J. (1993) Operation conditions affecting the performance of airlift reactors for immobilized enzyme reactions, Biotechnol. Techn. 7, 317-322.

30. Eddy, A. A. (1955) Flocculation characteristics of yeasts II. Sugars as dispersing agents, J. Inst. Brew. 61, 313-317.

31. Stratford, M. and Carter, A. T. (1993) Yeast flocculation: Lectin synthesis and activation, Yeast 9, 371-378.

32. Lei, H., Zhao, H., Yu, Z., and Zhao, M. (2012) Effects of wort gravity and nitrogen level on fermentation performance of brewer's yeast and the formation of flavor volatiles, Appl. Biochem. Biotechnol. 166, 1562-1574.

33. Smit, G., Straver, M. H., Lugtenberg, B. J., and Kijne, J. W. (1992) Flocculence of Saccharomyces cerevisiae cells is induced by nutrient limitation, with cell surface hydrophobicity as a major determinant, Appl. Environ. Microbiol. 58, 3709-3714.

34. Dengis, P. B., Nelissen, L. R., and Rouxhet, P. G. (1995) Mechanisms of yeast flocculation: Comparison of top- and bottom-fermenting strains, Appl. Environ. Microbiol. 61, 718-728.

35. Jin, Y.-L., Ritcey, L. L., Speers, R. A. R., and Dolphin, P. J. (2001) Effect ofcellsurface hydrophobicity, charge and zymolectin density on the flocculation of Saccharomyces cerevisiae, J. Am. Soc. Brew. Chem. 59, 1-9.

36. Soares, E. V., Vroman, A., Mortier, J., Rijsbrack, K., and Mota, M. (2004) Carbohydrate carbon sources induce loss of flocculation of an alebrewing yeast strain, J. Appl. Microbiol. 96, 1117-1123.

37. Soares, E. V. and Vroman, A. (2003) Effect of different starvation conditions on the flocculation of Saccharomyces cerevisiae, J. Appl. Microbiol. 95, 325-330.

38. Stratford, M., Coleman, H. P., and Keenan, M. (1988) Yeast flocculation: A dynamic equilibrium, Yeast 4, 199-208.

39. Panteloglou, A. G., Smart, K. A., and Cook, D. J. (2012) Malt-induced premature yeast flocculation: Current perspectives, J. Ind. Microbiol. Biotechnol. 39, 813-822.

40. Brányik, T., Vicente, A. A., Cruz, J. M., and Teixeira, J. A. (2002) Continuous primary beer fermentation with brewing yeast immobilized on spent grains, J. Inst. Brew. 108, 410-415.

41. Kumar, S., Singh, S. P., Mishra, I. M., and Adhikari, D. K. (2011) Continuous ethanol production by Kluyveromyces sp. IIPE453 immobilized on bagasse chips in packed bed reactor, J. Pet. Technol. Altern. Fuels 2, 1-6.

42. Smogrovicová, D., Dömény, Z., Gemeiner, P., Malovikova, A., and Sturdik, E. (1997) Reactors for continuous primary beer fermentation using immobilised yeast, Biotechnol. Techn. 11, 261-264.

43. Kunze, W. (2010) Beer production, in Technology Brewing and Malting, pp. 367-525, VLB, Berlin.

44. Michels, C. A. and Romanowski, A. (1980) Pleiotropic glucose repression-resistant mutation in Saccharomyces carlsbergensis, J. Bacteriol. 143, 674-679.

45. Novak, S., D'Amore, T., and Stewart, G. G. (1990) 2-Deoxy-D-glucose resistant yeast with altered sugar transport activity, FEBS Lett. 269, 202-204.

46. Kodama, Y., Fukui, N., Ashikari, T., Shibano, Y., Morioka-Fujimoto, K., Hiraki, Y., and Nakatani, K. (1995) Improvement of maltose fermentation efficiency: Constitutive expression of MAL genes in brewing yeast, J. Am. Soc. Brew. Chem. 563, 24-29.

47. Brányik, T., Vicente, A. A., Cruz, J. M., and Teixeira, J. A. (2004) Continuous primary fermentation of beer with yeast immobilized on spent grains - the effect of operational conditions, J. Am. Soc. Brew. Chem. 62, 29-34.
48. Hazelwood, L. A., Daran, J. M., van Maris, A. J., Pronk, J. T., and Dickinson, J. R. (2008) The Ehrlich pathway for fusel alcohol production: A century of research on Saccharomyces cerevisiae metabolism, Appl. Environ. Microbiol. 74, 2259-2266.

49. Sentheshanuganathan, S. (1960) The mechanism of the formation of higher alcohols from amino acids by Saccharomyces cerevisiae, Biochem. J. 74, 568-576.

50. Oshita, K., Kubota, M., Uchida, M., and Ono, M. (1995) Clarification of the relationship between fusel alcohol formation and amino acid assimilation by brewing yeast using 13C-labeled amino acid, in Proc. Eur. Brew. Conv. Congr. Brussels, pp. 387-402, IRL Press, Oxford.

51. Ryder, D. S. and Masschelein, C. A. (1985) The growth process of brewing yeast and the biotechnological challenge, J. Am. Soc. Brew. Chem. 43, 66-75.

52. Smogrovicová, D. and Dömény, Z. (1999) Beer volatile by-product formation at different fermentation temperature using immobilized yeasts, Process Biochem. 34, 785-794.

53. Mensour, N. A., Margaritis, A., Briens, C. L., Pilkington, H., and Russell, I. (1997) New developments in the brewing industry using immobilised yeast cell bioreactor systems, J. Inst. Brew. 103, 363-370.

54. Pajunen, E., Tapani, K., Berg, H., Ranta, B., Bergin, J., Lommi, H., and Viljava, T. (2001) Controlled beer fermentation with continuous on-stage immobilized yeast reactor, in Proc. Eur. Brew. Conv. Congr. Budapest, CD ROM, Fachverlag Hans Carl, Nürenberg.

55. Engan, S. (1972) Organoleptic threshold values of some alcohols and esters in beer, J. Inst. Brew. 78, 33-36.

56. Smogrovicová, D., Dömény, Z., Navrátil, M., and Dvorák, P. (2001) Continuous beer fermentation using polyvinyl alcohol entrapped yeast, in Proc. Eur. Brew. Conv. Congr. Budapest, CD ROM, Fachverlag Hans Carl, Nürenberg.

57. MacDonald, J., Reeve, P. T. V., Ruddlesden, J. D., and White, F. H. (1984) Current approaches to brewery fermentations, Prog. Ind. Microbiol. 19, 47-198.

58. Meilgaard, M. C. (1975) Flavour chemistry of beer. Part I: Flavour interaction between principal volatiles, Techn. Q. Master Brew. Assoc. Am. 12, 107-117.

59. Virkajärvi, I. and Kronlöf, J. (1998) Long-term stability of immobilized yeast columns in primary fermentation, J. Am. Soc. Brew. Chem. 56, 70-75.

60. Andersen, K., Bergin, J., Ranta, B., and Viljava, T. (1999) New process for the continuous fermentation of beer, in Proc. Eur. Brew. Conv. Congr. Cannes, pp. 771-778, IRL Press, Oxford.

61. Kronlöf, J. and Virkajärvi, I. (1999) Primary fermentation with immobilized yeast, in Proc. Eur. Brew. Conv. Congr. Cannes, pp. 761-770, IRL Press, Oxford.

62. Shen, H. Y., Moonjai, N., Verstrepen, K. J., Delvaux, F., and Delvaux, F. R. (2003) Immobilization of Saccharomyces cerevisiae induces changes in the gene expression levels of HSP12, SSA3 and ATF1 during beer fermentation, J. Am. Soc. Brew. Chem. 61, 175-181.

63. Verstrepen, K. J., Van Laere, S. D., Vanderhaegen, B. M., Derdelinckx, G., Dufour, J. P., Pretorius, I. S., Winderickx, J., Thevelein, J. M., and Delvaux, F. R. (2003) Expression levels of the yeast alcohol acetyltransferase genes ATF1, Lg-ATF1, and ATF2 control the formation of a broad range of volatile esters, Appl. Environ. Microbiol. 69, 5228-5237. 